\title{
Coffee Production in Kavre and Lalitpur Districts, Nepal
}

\author{
Yogendra Kumar Karki ${ }^{1 @}$, Punya Prasad Regmi ${ }^{2}$ and Resham Bahadur Thapa ${ }^{2}$ \\ ${ }^{1}$ Ministry of Agricultural Development, Singhadurbar, Kathmandu, Nepal; @: ykkarkee@hotmail.com \\ ${ }^{2}$ Institute of Agriculture and Animal Sciences, Tribhuvan University, Kathmandu, Nepal; PPR <punyaregmi@gmail.com>; RBT \\ <profrbthapa@gmail.com > \\ Received 12 June 2016, Revised 5 January 2017, Accepted 24 April 2017, \\ Published 28 April 2018 \\ Scientific Editors: Umesh Acharya, Ram B. KC, Dhruba Bhattarai and Tek \\ Prasad Gotame \\ Copyright $(\mathrm{C} 2018$ NARC. Permits unrestricted use, distribution and reproduction \\ in any medium provided the original work is properly cited.

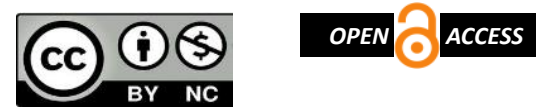 \\ Licensed under the Creative Commons Attribution- \\ NonCommercial 4.0 International (CC BY-NC 4.0)
}

\begin{abstract}
Coffee (Coffea spp) is an important and emerging cash crop having potential to provide farmers employment and income generation opportunities. This crop is well adapted to the climatic conditions of mid-hills of Nepal. Thus, majority of the farmers are attracted towards cultivation of coffee because of demands in national and international market. Coffee is now becoming integral part of farming system in rural areas. However, information on performance of coffee and farmers response has not been well documented. Therefore, we undertook the present work to analyze demography, ethnicity, household occupation, literacy status, average land holding, coffee cultivation area, livelihood and sources of income of coffee growers, production and productivity, pricing, cropping pattern of the coffee and problesm faced by them in mid hill district of Kavrepalanchowk (hereafter 'Kavre') and Lalitpur Districts. All the samples were taken randomly and selected from coffee producing cooperative of Kavre and Lalitpur. Our analysis showed that the male farmer dominant over female on adopting coffee cultivation in both districts with higher value in Kavre. Brahmin and Chetri ethnic communities were in majority over others in adopting the coffee cultivation. Literate farmers were more dominant over illiterates on adopting the coffee cultivation, The mean land holding was less, ranging from 0.15 to 2.30 ha for coffee cultivation, the history of coffee cultivation in Kavre showed that highest number of farmers were engaged in coffee farming from last 16 years. The mean yield of fresh cherry was $1027.20 \mathrm{~kg} / \mathrm{ha}$ in Kavre, while it was $1849.36 \mathrm{~kg} / \mathrm{ha}$ in Lalitpur. The study revealed that majority of the coffee plantations were between 6-10 years old. The major problems facing by coffee farmers were diseases spread, lack of irrigation facility and drying of plants. Despite of that the coffee farming was one of the rapidly emerging occupations among the farmers in both district of Nepal.
\end{abstract}

Keywords: Coffee, Production, Cropping pattern

सारंश

किसानहरुलाई रोजगारी र आय आर्जनको अवसरहरु प्रदान गर्ने क्षमता भएको कफी एक महत्वपर्ण र उदीयमान नगदे बाली हो। यो बाली नेपालको मध्य पहाडको जलवायु अनुकुल रहेको छ। यस बालीको राष्ट्रिय र अर्त्तराष्ट्रिय बजारमा उच्च मूल्य हुने भएको हुनाले धेरै जसो किसानहरु कफी खेतितिर आकर्षित छन्। अहिलेको अवस्थामा ग्रामीण क्षेत्रमा कफी खेती प्रणाली एक अभिन्न अंग बन्दै गएको छ। तथापि, कफि खेती बारे देशमा अक धेरै जानकारी रहेको अवस्था नभएकोले यस बाली सम्बन्धी ज्ञान संकलन गर्ने उद्देश्यले जनवरी २०१६ मा नेपालको काभ्रेपलाज्चोक र ललितपुर जिल्लाहरुका कफी उत्पादकहरुसंग यो अध्ययन संचालन गरिएको थियो। धैरै जसो किसानहरुले मकै आधारित बाली प्रणाली अवलम्बन गरेको पाइयो। उत्तरदाताहरु मध्ये कफीको चेरीको औशत उत्पादकत्व क्रमश: काभ्रेपलान्चोक र ललितपुर जिल्लामा १०२७.२० किलो प्रति हेक्टर र १५७९.३६ किलो प्रति हेक्टर रहेको पाइयो। अध्ययनले कफी बोटहरु प्रायः ६-१० बर्षका रहेका पाइयो। कफी उत्पादन बाहेक किसानहरु पशुपालनमा पनि संलग्न भएको पाइयो, जुन कफी उत्पादकहरुमा आयको अर्को प्रमुख श्रोतको रूपमा रहेको पाइयो। अतः कफी खेति एक महत्वपुर्ण बालीको रुपमा किसानहरुले स्वीकार गरि रहेको अवस्थाको आकलन गरिएको छ।

\section{INTRODUCTION}

Coffee is one of the important cash generative crops in the mid hills of Nepal (Chaudhary et al 2008, Paudel et al 2009, Tiwari 2010, Aoki and Suvedi 2012). It contains 0.1-0.3\% caffeine in instant coffee which stimulates and brings refreshers to human being after drink (Gautam and Dhakal 1994). It is reported that the coffee farming in Nepal was first introduced into Aanpchaur of Gulmi District in Nepal (Paudyal 2012). Then gradually spreading in nearby mid hill location rapidly. The Nepalese coffee has also been able to create market demand abroad (Dahal and Dhakal 2009, Aoki and Suvedi 2012, Khanna 2016) as well in the country probably because of aroma, taste, flavor and healthy and suitable environmental conditions where these coffees are produced from hilly slopes. 
Nepali coffee are mostly produced organically (Aoki and Suvedi 2012). Demand of Nepalese coffee is high and it fetch high price in international markets but still the demand has not been fulfilled because of low production. New coffee industries are increasing with anticipation that the production will increase however, it is known that factories are running below their capacity. Previous study (MoAD 2014) has shown that productivity of Nepalese coffee is poor only producing $224.7 \mathrm{~kg} / \mathrm{ha}$ as compared to other countries like Vietnam, Costarica and India. The productivity of Nepalese coffee has been estimated only to be $800 \mathrm{~kg}$ per hectare (Gautam et al 2008). In Nepal, coffee is cultivated in limited land under upland conditions without use of external inputs including chemical fertilizers and pesticides (Shrestha et al 2008; Khanna 2016).

Currently, coffee is cultivated in around 40 districts but commercial cultivation is done in around 20-22 hilly districts covering of Mid, Western and Eastern Development Regions of Nepal (MoAD 2014). In Nepal, coffee is predominately grown by resource poor and small scale farmers to sustain their livelihood under marginal upland condition (Shrestha et al 2008; Sharma et al 2015). The past report suggests that coffee is a potential crop which for revenue generation potentialities to poor marginalized farmers especially of mid-hills region enriched with suitable land and climatic condition for growing the coffee successfully (Sharma et al 2015; Paudel et al 2017). Although the expansion of coffee farming is rapid, but assessment of productivity and production from mid hill districts are yet to be carried out in detail. Therefore, we surveyed the status of production, productivity, farmer's perceptions, cropping system and economic analysis of coffee farmers in two mid hill districts located near to Kathmandu

\section{MATERIALS AND METHODS}

The present survey was carried out in the month of January 2016 using semi-structure questionnaire to collect the data. Prior to survey, pretesting of questionnaire was done. The survey was focused to coffee farmers group and cooperatives. There were altogether 180 respondents who were involved in coffee farming and allied cooperatives in Kavre and Lalitpur districts of Nepal. All the samples were taken randomly from available six primary coffee cooperatives that were associated with coffee production. Data were analyzed by using SPSS. Secondary data were taken from Ministry of Agricultural Development, Nepal. Compounded annual growth rate (CAGR) for area, production and productivity of Kavre and Lalitpur districts were calculated using formula:

$\mathrm{Y}_{\mathrm{t}}=\mathrm{AB}^{\mathrm{t}}$, where, $\mathrm{Y}_{\mathrm{t}}=$ Year; $\mathrm{A}=$ Intercept $\mathrm{B}=$ Area/Production/Export $/$ Import $;{ }^{\mathrm{t}}=$ Time

\section{RESULTS}

Demographic Situation

The general information of respondents in terms of gender, ethnicity, occupation, education, and land holding size were appraised as given in Table 1. Out of 180 respondents, majority of respondents $(89.44 \%)$ were male. Only 10.56 percent were female. The ratio of male to female was higher in Kavre district than in Lalitpur district.

Table 1. Respondents by gender and district $(n=180)$

\begin{tabular}{llllcccc}
\hline Gender & \multicolumn{3}{c}{ Kavre } & \multicolumn{3}{c}{ Lalitpur } & Total \\
\cline { 2 - 8 } & Number & $\boldsymbol{\%}$ & Number & $\boldsymbol{\%}$ & Number & \\
\hline Male & 82 & 91.11 & 79 & 87.77 & 161 & 89.44 \\
\hline Female & 8 & 8.89 & 11 & 12.22 & 19 & 10.56 \\
\hline Total & 90 & 100 & 90 & 100 & 180 & 100 \\
\hline
\end{tabular}

The survey showed that 88.33 per cent of respondents were Brahman and Chettri and only $11.67 \%$ were Janajati (Table 2). Lalitpur have relatively higher number of Janajati engaged in coffee production than Kavre.

Table 2. Classification of respondents based on ethnicity system by district $(n=180)$

\begin{tabular}{lrrrrrrr}
\hline \multirow{2}{*}{ Ethnicity } & \multicolumn{2}{c}{ Kavre $(\mathbf{n = 9 0}$} & \multicolumn{2}{c}{ Lalitpur $(\mathbf{n = 9 0}$} & \multicolumn{2}{c}{ Total } \\
\cline { 2 - 8 } & Number & \multicolumn{9}{c}{} & Number & \% & Number & \% \\
\hline Janajati & 5 & 5.56 & 16 & 17.78 & 21 & 11.67 \\
\hline Brahman/Chettri & 85 & 94.44 & 74 & 82.22 & 159 & 88.33 \\
\hline Total & 90 & 100 & 90 & 100 & 180 & 100 \\
\hline
\end{tabular}

The occupational involvement of coffee farming community showed that agriculture was major occupation among majority of the households (Table 3). The result showed that $87.78 \%$ of respondents were engaged in agriculture while $7.28 \%$ were in other services. Higher number of respondents from Kavre was involved in agriculture than Lalitpur. 
Table 3. Major occupation of household head by district $(n=180)$

\begin{tabular}{lcccccr}
\hline Occupation & \multicolumn{2}{c}{ Kavre } & \multicolumn{3}{c}{ Lalitpur } & \multicolumn{2}{c}{ Total } \\
\cline { 2 - 7 } & No. & \% & No. & \% & No. & \% \\
\hline Agriculture & 82 & 91.11 & 76 & 84.44 & 158 & 87.78 \\
\hline Service & 4 & 4.44 & 9 & 10.00 & 13 & 7.22 \\
\hline Business & 2 & 2.22 & 3 & 3.33 & 5 & 2.78 \\
\hline Daily wages & & 0.00 & 2 & 2.22 & 2 & 1.11 \\
\hline Others & 2 & 2.22 & 0 & 0.00 & 2 & 1.11 \\
\hline Total & 90 & 100 & 90 & 100 & 180 & 100 \\
\hline
\end{tabular}

The survey revealed that there were two categories of qualification level of respondents, one was literate and another illiterate; nearly one fourth of the respondents were illiterate in both districts. Out of 180 respondents, 41 were illustrate and remaining 139 were literate. The number of literate respondent in Lalitpur was higher (72) comparing to Kavre (67) as shown in Table 4.

Table 4. Literacy status of respondents by district $(n=180)$

\begin{tabular}{lcccccrr}
\hline Education status & \multicolumn{2}{c}{ Kavre $(\mathbf{n = 9 0}$} & \multicolumn{2}{c}{ Lalitpur $(\mathbf{n}=\mathbf{9 0})$} & \multicolumn{2}{c}{ Total } \\
\cline { 2 - 8 } & Number & $\mathbf{\%}$ & Number & $\mathbf{\%}$ & Number & \% \\
\hline Literate & 67 & 74.44 & 72 & 80 & 139 & 77.22 \\
\hline Illiterate & 23 & 25.55 & 18 & 20 & 41 & 22.78 \\
\hline Total & 90 & 100 & 90 & 100 & 180 & 100 \\
\hline
\end{tabular}

Our survey showed that the average land holding of respondents were 0.78 ha including both khet and bari in study location (Table 5). The term Khet indicate to irrigated paddy field while Bari is the term used for unirrigated farm land. Respondents from Lalitpur districts have more average land size ( 0.81 ha) than in Kavre (0.74 ha). The range for bari land is also higher in Lalitpur. In both districts the majority of the land did not have irrigation facilities developed.

Table 5. Average size of landholding by type of land and district (ha)

\begin{tabular}{|c|c|c|c|c|c|c|c|c|c|}
\hline \multirow[t]{2}{*}{ Type of Land } & \multicolumn{3}{|c|}{ Kavre $(\mathbf{n}=90)$} & \multicolumn{3}{|c|}{ Lalitpur $(\mathrm{n}=90)$} & \multicolumn{3}{|c|}{ Total } \\
\hline & Min & Max & Mean & Min & Max & Mean & Min & Max & Mean \\
\hline Khet & 0.00 & 1.25 & 0.29 & 0.00 & 0.75 & 0.14 & 0.00 & 1.25 & 0.22 \\
\hline Bari & 0.10 & 1.50 & 0.47 & 0.10 & 2.30 & 0.69 & 0.10 & 2.30 & 0.58 \\
\hline $\begin{array}{l}\text { Total } \\
\text { (Khet+Bari) }\end{array}$ & 0.15 & 2.05 & 0.74 & 0.15 & 2.30 & 0.81 & 0.15 & 2.30 & 0.78 \\
\hline \multicolumn{10}{|l|}{ Nature of land } \\
\hline Irrigated & 0.00 & 1.40 & 0.24 & 0.00 & 0.75 & 0.17 & 0.00 & 1.40 & 0.22 \\
\hline Unirrigated & 0.00 & 1.50 & 0.48 & 0.00 & 2.00 & 0.59 & 0.00 & 2.00 & 0.54 \\
\hline
\end{tabular}

History of Coffee Cultivation

Coffee cultivation in study districts was started from past 40 years. It has been categorized the respondents into four category based on the year of cultivation of coffee. Majority of the coffee producers have 6 to 10 years of coffee cultivation experiences which was higher in both districts as compared to other categories. Study revealed that more number of respondents (16) has started cultivating coffee before sixteen year in Kavre as compared to respondents of Lalitpur. There were significant differences in year of cultivation between two districts.

Table 6. Years of coffee cultivation by district

\begin{tabular}{lccc}
\hline Years of cultivation & \multicolumn{2}{c}{ Districts } & Total \\
\cline { 2 - 4 } & Kavre & Lalitpur & 42 \\
\hline$<5$ years & 26 & 16 & 70 \\
\hline $6-10$ years & 28 & 42 & 48 \\
\hline $11-15$ year & 22 & 26 & 20 \\
\hline$>16$ year & 14 & 6 &
\end{tabular}

Chi-square value $=8.7143 *(p$-value $=0.033) *$ Significant at $5 \%$ level 
Area and production of coffee

There was increase in area and production of coffee in Kavre. Annual compounded growth rate of area was 2.35 per cent per year and for production of parchment was 10.80 per cent in Kavre. In case of Lalitpur, annual compounded growth rate (ACGR) for area was higher (10.64\%) but the production growth rate was similar to that of Kavre. Although the productivity was higher in Lalitpur but it decreased from 2010/11 (MoAD 2011)

Table 7. Area, production and productivity of coffee in different years by district

\begin{tabular}{|c|c|c|c|c|c|c|}
\hline \multirow[t]{2}{*}{ Year } & \multicolumn{3}{|c|}{ Kavre } & \multicolumn{3}{|c|}{ Lalitpur } \\
\hline & $\begin{array}{l}\text { Area } \\
\text { (ha) }\end{array}$ & Production (mt) & $\begin{array}{l}\text { Productivity } \\
\text { (kg/ha) }\end{array}$ & Area (ha) & $\begin{array}{l}\text { Production } \\
\text { (mt) }\end{array}$ & $\begin{array}{l}\text { Productivity } \\
\text { (kg/ha) }\end{array}$ \\
\hline $2003 / 04$ & 110 & 12 & 109.09 & 40 & 21 & 525.00 \\
\hline $2004 / 05$ & 110 & 11.25 & 102.27 & 40 & 23.5 & 587.50 \\
\hline $2005 / 06$ & 115 & 22 & 191.30 & 70 & 25 & 357.14 \\
\hline $2006 / 07$ & 115 & 17 & 147.83 & 70 & 40 & 571.43 \\
\hline $2007 / 08$ & 116.5 & 30 & 257.51 & 70 & 30 & 428.57 \\
\hline $2008 / 09$ & 110 & 23 & 209.09 & 97 & 46.8 & 482.47 \\
\hline $2009 / 10$ & 118 & 26 & 220.34 & 104 & 54 & 515.04 \\
\hline $2010 / 11$ & 130 & 35 & 269.23 & 115 & 48 & 415.65 \\
\hline $2011 / 12$ & 130 & 35.50 & 273.08 & 115 & 35.50 & 308.70 \\
\hline $2012 / 13$ & 117 & 28 & 239.32 & 92 & 27.6 & 300.00 \\
\hline $2013 / 14$ & 155 & 36 & 232.26 & 120 & 31.5 & 262.50 \\
\hline ACGR & $2.35 \%$ & $10.80 \%$ & $8.45 \%$ & $10.64 \%$ & $4.25 \%$ & $-6.40 \%$ \\
\hline
\end{tabular}

Source: Statistical Information on Nepalese Agriculture 2003-2014. ACGR, Annual compounded growth rate

Production Status

The study showed that farmers planted coffee in an average of 0.224 ha in Kavre and 0.219 ha in Lalitpur. Similarly, the production of fresh cherry by individuals household is on an average of $170.20 \mathrm{~kg}$ for Kavre and $283.2 \mathrm{~kg}$ for Lalitpur. The productivity is higher in Lalitpur (1849.36 kg fresh cherry per hectare) in comparison to Kavre (1027.20 kg fresh cherry per hectare) during last year. The total productivity in study district is $1440.87 \mathrm{~kg} / \mathrm{ha}$. Most of the coffees produced were found to sale and negligible amount were stored for home consumption (Table 8). The average rate for sale of cherry was 103.87 in Kavre, 116.46 in Lalitpur and NRs. 110.13 per $\mathrm{kg}$ for all the respondents in study area.

Table 8. Average area, production, productivity and price of coffee by district

\begin{tabular}{lccccr}
\hline District & Area $(\mathbf{h a})$ & Production $(\mathbf{k g})$ & Productivity $(\mathbf{k g} / \mathbf{h a})$ & Sale $(\mathbf{k g})$ & Selling Price $(\mathbf{N R s} / \mathbf{k g})$ \\
\hline Kavre & 0.224 & 170.2 & 1027.20 & 169.93 & 103.87 \\
\hline Lalitpur & 0.219 & 283.2 & 1849.36 & 282.72 & 116.46 \\
\hline Total & 0.221 & 227.7 & 1440.87 & 223.09 & 110.13 \\
\hline
\end{tabular}

\section{Cropping Pattern}

Coffee producers have found to adopt various cropping pattern beside coffee production for their livelihood. Maize is major crop after coffee and they also prefer potato, mustard and finger millet after maize cultivation (Table 9). Ginger is becoming new crop to the producers in Lalitpur and majority of farmers are adopting ginger because it has high value in market. In focus group discussion with coffee producers, it is found that they were adopting banana as new shade plants which have double advantages first benefit is for shade to the coffee plants and second is earning from banana sale. Some of the major cropping patterns adopted by the coffee producers are as follows.

Maize-Ginger

Maize-Mustard

Maize-Potato

Wheat-Potato/Mustard- Maize

Rice-Maize-Finger millet/Mustard

\section{Maize-Finger Millet}

Rice-Potato-Maize

Rice-Maize

Rice-Maize-Potato

\section{Sources of Livelihoods}

Livestock play important role to the coffee producers as study showed they earned on an average NRs. 105150 per year from sale of milk and milk products. Similarly, coffee cultivation is also one of the major sources of income to the farmers. It contributes NRs. 21670 and 31868 per year to the farmers of Kavrepalanchock and Lalitpur, respectively. In total farmers earn average of NRs. 26949 per year from coffee cultivation, which has 
been greatly contributing in sustaining their livelihoods. Other source of income includes vegetables, fruits, service, pension and daily wages.

Problems associated with coffee production

Majority of the respondents $(45.56 \%)$ reported that lack of irrigation was major obstacle for coffee production. Coffee disease especially coffee leaf rust was another problem $(30.14 \%)$. Other problems related with coffee production were drying of plants, lack of manure, lack of seed materials, and lack of training respectively.

Table 10. Various sources of income and average amount earned by district

\begin{tabular}{lcccccc}
\hline \multirow{2}{*}{\begin{tabular}{l} 
Incource of \\
\cline { 2 - 7 }
\end{tabular}} & $\begin{array}{c}\text { Amount } \\
\text { (NRs.) }\end{array}$ & $\begin{array}{c}\text { Number of } \\
\text { Respondents }\end{array}$ & $\begin{array}{c}\text { Amount } \\
\text { (NRs.) }\end{array}$ & $\begin{array}{c}\text { Number of } \\
\text { Respondents }\end{array}$ & $\begin{array}{c}\text { Amount } \\
\text { (NRs.) }\end{array}$ & $\begin{array}{c}\text { Number of } \\
\text { Respondents }\end{array}$ \\
\hline Coffee & 21670.73 & 82 & 31868.18 & 88 & 26949.41 & 170 \\
\hline Vegetables & 21750.00 & 16 & 15727.27 & 22 & 18263.16 & 38 \\
\hline Fruits & 6833.33 & 6 & 10111.11 & 9 & 8800.00 & 15 \\
\hline Livestock & 105150.0 & 60 & 53280.00 & 50 & 81572.73 & 110 \\
\hline Others & 37545.45 & 22 & 9000.00 & 6 & 31428.57 & 28 \\
\hline Services & 93894.74 & 19 & 162666.67 & 21 & 130000.0 & 40 \\
\hline Business & 21285.71 & 7 & 87272.73 & 11 & 61611.11 & 18 \\
\hline Daily wages & 15038.46 & 13 & 115888.89 & 9 & 56295.45 & 22 \\
\hline Pension & 60500.00 & 4 & 48666.67 & 3 & 55428.57 & 7 \\
\hline
\end{tabular}

Table 10. Different type of problems associated with coffee production

\begin{tabular}{|c|c|c|c|}
\hline \multirow[t]{2}{*}{ Problem } & \multicolumn{2}{|c|}{ Districts } & \multirow{2}{*}{$\begin{array}{c}\text { Total } \\
(\mathbf{n}=\mathbf{1 8 0})\end{array}$} \\
\hline & Kavre $(n=90)$ & Lalitpur $(n=90)$ & \\
\hline Coffee Disease & 53 & 76 & $129(30.14)$ \\
\hline Drying of plants & 25 & 14 & $39(9.11)$ \\
\hline Earthquake & 3 & 0 & $3(0.70)$ \\
\hline Lack of irrigation facility & 107 & 88 & $195(45.56)$ \\
\hline Lack of manure & 8 & 2 & $10(2.33)$ \\
\hline Lack of training & 13 & 8 & $21(4.91)$ \\
\hline Insect problem & 5 & 5 & $10(2.33)$ \\
\hline Lack of seed material & 6 & 2 & $8(1.87)$ \\
\hline Lack of market & 4 & 0 & $4(0.94)$ \\
\hline Problem of shade & 3 & 6 & $9(2.10)$ \\
\hline
\end{tabular}

Figures in the parenthesis indicate the percentage

\section{DISCUSSION}

Although coffee cultivation in Nepal started in 1938 AD, its commercial value increases after 2002, at present more than 40 districts have adopted coffee cultivation including Lalitpur and Kavre (NTCDB 2016). The present survey showed that usually per household average coffee plantation area in an average covers 0.224 ha in Kavre while 0.219 ha in Lalitpur. However, the average coffee plantation in Nepal has been reported to be 1.4 ha consisting of Bari or uplands. The average mean of fresh coffee yield per hectare in 2007 was $2450 \mathrm{~kg}$, ranging from 250 to $8140 \mathrm{~kg}$ per hectare (Kattel 2009). In present study the average productivity is higher in Lalitpur (1849.36 kg fresh cherry per hectare) in comparison to Kavre (1027.20 kg fresh cherry per hectare) during 2015 . The total productivity in study districts ranged $1440.87 \mathrm{~kg} / \mathrm{ha}$.

Tiwari (2010) showed that about $65 \%$ of Nepalese coffee is exported and the rest is processed and supplied in domestic market. Contrarily to such situation Nepal imports coffee from overseas countries to meet domestic demand. Generally instant coffee is in imported in Nepal. It is observed that Nepalese coffee is consumed mostly and foreign tourist and residents over the instant ones. This might be one of the reasons why the demand for Nepalese coffee is growing in the domestic market (AEC-FNCCI 2006, Kattel 2017). It is learnt that the Nepalese coffee in the international market require to maintain consistent quality and quantity. According to AEC-FNCCI (2006) world coffee production grew at an annual rate of 3.6\% in the last 10 years, but the demand had increased only by $1.3 \%$, suggesting that there is a competitive state in coffee marketing. In our study area the production has increased $10.80 \%$ in (Kavre) and $4.25 \%$ (Lalitpur).

The normal life expectancy of a coffee plant has been estimated to be of 45 years or above (Panthi 2014). In Nepal some of the farmers owning the coffee tree since last 40 years, while in the study area majority of farmers 
have 6-10 years age of coffee plants Coffee plants requires regular watering especially during the first and second year of plantation for higher productivity. Maintenance of moisture is crucial by applying organic manure, shades management and mulching. However, lack of irrigation facility is a major problem among farmers for declining production of coffee.

According to Panthi (2014), coffee plantation in Lalitpur district was intercropped with fruits, where coffee plants share $33 \%$ area with fruits orchard, followed by fodder trees $(>24 \%)$, cash crops $(>16 \%)$, vegetables $(>2.5 \%)$ and grasses $(>1 \%)$. In the study area, banana was the major fruits cultivated along with coffee plantation. Other nine different cropping patterns have been identified, which require further to be studied.In general, we found that coffee farmers obtaining an average benefit of NRs. 26949 per year which is in average $5.73 \%$ of total income of the respondents in both districts. Previously, the contribution of coffee in annual income reported was 10\% Acharya and Dhakal (2014).

Coffee cultivation has important role in livelihood of farmers in Kavre and Lalitpur districts where coffee was under cultivation since 40 years. Majority of farmers are planting and growing more trees to produce coffee in commercial way since last 10 years. Although average area of cultivation $(0.224$ ha) is higher in Kavre, Productivity of cherry is higher in Lalitpur $(1849.36 \mathrm{~kg} / \mathrm{ha})$ in comparison to Kavre $(1027.20 \mathrm{~kg} / \mathrm{ha})$. After coffee, maize is another major crop farmers prefer to incorporate in different cropping system. This study showed that other various other cropping pattern are practiced in study area (Table 9). Coffee producers also earn substantial amount of money from livestock as another source of earning (Table 10). Others sources of earning includes services in governmental and non-governmental organizations, daily wages and business. Although area of coffee cultivation is increasing in study areas however, the production of coffee is low comparatively in Lalitpur. Therefore, major efforts should be directed to find out the solutions to increase coffee production in these districts.

\section{ACKNOWLEDGEMENT}

We extend my gratitude to supporting staffs to Ministry of Agriculture, Land Management and Cooperatives for and coffee farmers for supporting in data collection.

\section{REFERENCES}

Aoki K and M Suvedi. 2012. Coffee as a Livelihood Support for Small Farmers: A Case Study of Hamsapur Village in Nepal, Journal ofInternational Agricultural and Extension Education. 19 (1):16-29. DOI: 10.5191/jiaee. 2012.19104

Acharya B and SC Dhakal. 2014. Profitability and major problems of coffee production in Palpa district, Nepal. Int J Appl Sci Biotechnol. 2(4): 460-463.

AEC-FNCCI. 2006. The study report on trade competitiveness of Nepalese coffee. May 2006. Kathmandu, Nepal.

Chaudhary JN, YR Bhusal, C Adhikari and RP Yadav. 2008. Performance Evaluation of Coffee Genotypes in the Western Hills of Nepal. In: Proceedings of the Fifth National Seminar on Horticulture, June 9-10, 2008. Kathmandu, Nepal.

Dahal KR and SC Dhakal. 2009. The Relative Efficiency of Organic Farming in Nepal, Published by the South Asian Network for Development and Environmental Economics (SANDEE), PO Box 8975, EPC 1056, Kathmandu, Nepal.p 18

Dhakal BR. 2005. Coffee Manual. First edition, National Tea and Coffee Development Board (NTCDB), New Baneshwor, Kathmandu.

Gautam DM and DD Dhakal. 1994. Fruit and Industrial Crops, IAAS, Central Campus, Rampur, Chitwan.

Gautam S, MB Nepali, D Gauchan, NS Thakur, B Sharma, SM Amataya and B Bhat. 2008. Economics of Coffee Production: A case Study of Sirubare of Syangja and Digam, Thanapati of Gulmi District. In: Proceedings of the Fifth National Seminar on Horticulture, June 9-10, 2008. Kathmandu, Nepal.

Kattel RR. 2009. The impact of coffee production on Nepali smallholders in the value chain. Institute of Environmental Economics and World Trade, Leibniz Universitate. Hannover, Germany. www.tropentag.de/2009/abstracts/full/464.pdf

Kattel RR. 2017. Impacts of group organic certification of coffee on Socio-economic and environmental sustainability in Nepal, Journal of Agriculture and Forestry University. 1: 49-60.

Khanna SA. 2016. Prospects of organic farming in hill farms of Nepal.Tropical Plant Research. 3(1): 70-77

MoAD. 2014. Statistical Information on Nepalese Agriculture 2014. Ministry of Agricultural Development. Singhdarbar, Kathmandu.

NTCDB. 2016. History of Coffee in Nepal. Accessed in 27 July 2016 from http://www.teacoffee.gov.np/en/detail.php?section=coffee\&nav_id=13\&nav_name=history-of-coffee-in-nepal.

Panthi BB. 2014. Small scale Coffee Farmer's Response towards Management of Coffee Pest through Field Level Techniques. Journal of Institute of Science and Technology.19(2): 37-44

Paudyal KR. 2012. Review of the coffee sub sector in Nepal. Proceedings of the workshop on Coffee sub-sector held on November 2012. Project for Agriculture Commercialization and Trade, Sallghari, Kathmandu.

Poudel KL, A Poudel Nepal, B Dhungana, Y Sugimoto, N Yamamoto and A Nishiwaki. 2009. Capital Budgeting Analysis of Organic Coffee Production in Gulmi District of Nepal. University of Miyazaki. Faculty of Agriculture. Department of Environment and Resource Sciences, Interdisciplinary Graduate School for Agriculture and Engineering. 
Poudel KL, B Mishra and Thomas G Johnson. 2017. Farm Efficiency and Its Determinants in Different Farm Size and Altitude Categories: A Case of Organic Coffee Cultivation in Nepal, Journal of Economic Insight (formerly the Journal of Economics (MVEA)). 43(1): 1-18

Sharma GP, R Pandit, B White and M Polyakov. 2015. The Income Diversification Strategies of Smallholder Coffee Producers in Nepal, Working Paper 1508, School of Agricultural and Resource Economics, University of Western Australia, Crawley, Australia

Shrestha PM, P Sharma and R Mishra. 2008. Production, Processing and Marketing of Coffee in Nepal. In: Proceedings of the Fifth National Seminar on Horticulture, June 9-10, 2008. Kathmandu, Nepal. Tiwari KP. 2010. Agricultural policy review for coffee promotion in Nepal. The Journal of Agriculture and Environment. 11:138-147.

Tiwari KP. 2010. Agricultural policy review for coffee promotion in Nepal, The Journal of Agriculture and Environment 11: 138-147. 